\title{
Commentary 11 to the Manifesto for the marine social sciences: culture and religion
}

\author{
Annet P. Pauwelussen ${ }^{1}$ \\ Published online: 3 July 2020 \\ (C) The Author(s) 2020
}

Across the world, maritime and sea-oriented societies show an outstanding diversity of practices, cultural expressions, and spiritual values related to the sea. Besides the multiplicity of religious and cultural traditions linked to sea-based ways of life (McGoodwin 2001), diversity is also found in how the human-marine relationship takes multiple forms. Considering different marine cultures - including science cultures (Knorr-Cetina 1999) — this also involves basic notions of what the sea is and how it is known and valued. Exploring and understanding such diversity is one of the empirical pillars of a marine social science agenda, as it revolves around the fundamental question of how humans relate to the sea.

Over the past decades, marine social science has approached this question predominantly through an instrumental lens, with a focus on fisheries. Other manifestations of the human-marine relationship such as wayfinding, affective encounters, or making knowledge and sense have been rather scattered throughout anthropological, geographical and affiliated literature (e.g., Brown and Peters 2018; Hayward 2010; Merchant 2011; Ota 2006; Pálsson 1994). Drawing a broader relationship between people and the sea, the Manifesto highlights (MMSS 1.1.6) the importance of " bringing to the fore the manifold realities of people and communities and their role in the production of knowledge and in coastal decision-making," an essential step towards understanding the cultural and spiritual manifestations of humanmarine relations. But how? To be able to pursue this line of inquiry, two points need to be emphasized. The first is about epistemological and ontological diversity, the second about the land bias in social science.

Annet P. Pauwelussen

annet.pauwelussen@wur.nl

1 Wageningen University and Research, Wageningen, Netherlands

\section{Epistemological and ontological diversity}

Across coastal cultures and seafaring societies, anthropologists have encountered ways of understanding and ordering marine reality that challenge the western-secular frameworks on which marine social science is commonly based. For example, research among sea-based Bajau in Malaysia shows a cyclical and tidal ordering of time at odds with the linear time frame that underlies the notion of sustainability (Clifton and Majors 2012). Likewise, conceptions of marine space by seafaring societies may not map onto Euclidian geometry and cartographic visualization used in participatory mapping (Turnbull 2007). Moreover, indigenous conceptions of the sea as a social assemblage of beings contrast with the modern idea of the natural and the social as distinct realms (Lowe 2006; Zerner 2003). Such discrepancies affect collaboration in management and conservation outreach (Pauwelussen and Verschoor 2017; Verschuuren et al. 2015).

While diversity may be explained as the existence of different perspectives on marine reality, the above examples illustrate a more radical — ontological — disparity when different understandings of reality cannot be reduced to each other's logics. In encountering such discrepancies in how the sea is experienced and understood, how can we understand difference in its own terms without reducing it to our own? Such approach makes room to take in logics and worldmaking that tend to escape scholarly attention yet affect how marine projects and policies are received. It also has political importance for a "decolonization of thought" (Viveiros de Castro 2014) in human sciences which requires deconstructing the privilege of modernity's mental landscape (Latour 1993). The modern science perspective is often taken as the ultimate reality to which other ways of understanding the world are reduced and measured, and marine science is no exception to this (Pauwelussen 2017). As the Manifesto points out, inter- and transdisciplinary methodologies are needed to strengthen the position of coastal populations (MMSS 3.4) and marine social science should contribute to the well-being of marginal and vulnerable 
people, including indigenous peoples (MMSS 3.2). Yet, as also pointed out by Holm (2003), the solution does not lie in adopting local or indigenous knowledge into science-based knowledge schemes, but by taking seriously a more radical diversity in how people know, value, and engage with the sea, also in our research design.

So, to bring to the fore the manifold realities of maritime communities, and their role in the production of knowledge as an urgent topic for marine social science (MMSS 1.1.6), we need to develop and experiment with conceptual and methodological tools to engage more fully with the multiplicity of marine realities and the kind of relations and logics they presuppose, enact, and sustain. This also requires marine social science to cultivate sensitivity to the epistemological and ontological asymmetries at work in marine science and governance, and to create the intellectual and political conditions for collaboration on equal terms across epistemological and ontological diversity in the production and use of marine social science knowledge.

\section{The prevailing land bias}

In the study and regulation of the sea, a terrestrial focus on maritime cultures prevails, in which communities and their practices are often spatially defined as extension of life on land. Putting the sea center stage as a dynamic field to do research in and from, sheds light on the trans-local and mobile ways in which people shape cultural and religious realities beyond land-based models (Nolde 2009; Tagliacozzo 2009), taking in also the myriad of material, spiritual, and non-human agencies involved in the dynamic assembling of the sea (Bear 2012)

The Manifesto (MMSS 1.1.1) urges us to explore the similarities, differences, and interlinkages that exist for people in terrestrial versus marine environments. To do this, marine social scientists also need to get their feet wet and engage in the everyday lives and travels of fishers, seafarers, and tradeswomen (Fabinyi 2013; Pauwelussen 2015; Stacey 2007) and follow scientists as they produce knowledge embedded in particular epistemic cultures (Helmreich 2009; Hornidge 2018). Qualitative research on and from islands, vessels, and reefs helps to address terrestrial bias in marine governance, to make policies better equipped to include mobile and trans-local assemblages through with marine realities take shape.

To do this in a thorough way, marine social science should also critically reflect on its own terrestrial bias in studying coastal and sea-based cultures. It matters how we define our social units of analysis, as sea-based and coastal communities, cultures, traditions, spirits realms, and knowledge systems tend to elude land-based categories of village, island, or region. Spatial categorization has political consequences when social science informs marine policy, a process that we need to take greater responsibility for (MMSS 2.1.1). Therefore, while MMSS 2.2.1 highlights the governance issue of including small-scale fishers and their traditional tenure rights in decision-making, we should not predefine their range of operation (cf St Martin and Olson 2017).

Marine social science should give more weight to explorative-qualitative social science research based on methodological iteration and experimentation corresponding to the diversity and mobility of marine realities, to complement deductive approaches. Doing so provides vital insights into the diversity of cultural and spiritual manifestation of the humansea relationship. Crucially, it also feeds into a necessary reflection on our research design, challenging basic spatial and ontological assumptions ingrained in how we approach marine reality.

Open Access This article is licensed under a Creative Commons Attribution 4.0 International License, which permits use, sharing, adaptation, distribution and reproduction in any medium or format, as long as you give appropriate credit to the original author(s) and the source, provide a link to the Creative Commons licence, and indicate if changes were made. The images or other third party material in this article are included in the article's Creative Commons licence, unless indicated otherwise in a credit line to the material. If material is not included in the article's Creative Commons licence and your intended use is not permitted by statutory regulation or exceeds the permitted use, you will need to obtain permission directly from the copyright holder. To view a copy of this licence, visit http://creativecommons.org/licenses/by/4.0/.

\section{References}

Bear, C. 2012. Assembling the sea: materiality, movement and regulatory practices in the Cardigan Bay scallop fishery. Cultural Geographies 20 (2): 21-41.

Brown, M, and K. Peters. 2018. Living with the sea: knowledge, awareness and action. London: Routledge.

Clifton, J., and C. Majors. 2012. Culture, conservation and conflict: perspectives on marine protection among the Bajau of Southeast Asia. Society \& Natural Resources 25 (7): 716-725.

Fabinyi, M. 2013. Social relations and commodity chains: the live reef fish for food trade. Anthropological Forum 23 (1): 36-57.

Hayward, E. 2010. Fingeryeyes: impressions of cup corals. Cultural Anthropology 25 (4): 577-599.

Helmreich, S. 2009. Alien ocean. Anthropological voyages in microbial seas. Berkeley: University of California Press.

Holm, P. 2003. Crossing the border: on the relationship between science and fishermen's knowledge in a resource management context. Maritime Studies 2 (1): 5-33.

Hornidge, A. 2018. A research vessel, heterotopia, boundary place and pluriverse of epistemes. In Wissensrelationen. Beiträge und Debatten zum 2, ed. Angelika Poferl and Michaela Pfadenhauer. Sektionskongress der Wissenssoziologie, Berz \& Juventa.

Knorr-Cetina, K. 1999. Epistemic cultures - how the sciences make knowledge. Cambridge: Harvard University Press.

Latour, B. 1993. We have never been modern. Cambridge: Cambridge University Press. 
Lowe, C. 2006. Wild profusion: biodiversity conservation in an Indonesian archipelago. Princeton: Princeton University Press.

McGoodwin, J. R. 2001. Understanding the cultures of fishing communities: a key to fisheries management and food security. FAO Fisheries Technical Paper. No. 401. Rome, FAO, 287p.

Merchant, S. 2011. Negotiating underwater space: the sensorium, the body and the practice of scuba-diving. Tourist Studies 11 (3): 214-234.

Nolde, L. 2009. 'Great is our relationship with the sea.' Charting the maritime realm of the Sama of Southeast Sulawesi, Indonesia. Explorations 9: 15-33.

Ota, Y. 2006. Fluid bodies in the sea: an ethnography of underwater spear gun fishing in Palau, Micronesia. Worldviews 10: 205-219.

Pálsson, G. 1994. Enskillment at sea. Man 29 (4): 901-927.

Pauwelussen, A.P. 2015. The moves of a Bajau middlewoman: exploring the disparity between trade networks and marine conservation. Anthropological Forum 25 (4): 329-349.

Pauwelussen, A.P. 2017. Amphibious anthropology: engaging with maritime worlds in Indonesia. $\mathrm{PhD}$ Thesis, Wageningen University.

Pauwelussen, A.P., and G.M. Verschoor. 2017. Amphibious encounters: coral and people in conservation outreach in Indonesia. Engaging Science, Technology and Society 3: 292-314.

St Martin, K., and J. Olson. 2017. Creating space for community in marine conservation and management: mapping "communities-atsea". In Conservation for the Anthropocene sea. Interdisciplinary science in support for nature and people, ed. P.S. Levin and M.R. Poe, 123-141. London: Elsevier.

Stacey, N. 2007. Boats to burn: Bajo fishing activity in the Australian fishing zone. Canberra: ANU E-Press.

Tagliacozzo, E. 2009. Navigating communities: race, place, and travel in the history of maritime Southeast Asia. Asian Ethnicity 10 (2): 97 120.

Turnbull, D. 2007. Maps, narratives and trails: performativity, hodology and distributed knowledge in complex adaptive systems - an approach to emergent mapping. Geographical Research 45 (2): 140 149.

Verschuuren, B., M. Zylstra, B. Yunupingu, and G.M. Verschoor. 2015. Mixing waters: a cross cultural approach to developing guidelines for fishers and boaters in the Dhimurru Indigenous Protected Area, Australia. Parks 21 (1): 73-88.

Viveiros de Castro, E. 2014. Cannibal metaphysics for a poststructural anthropology, translated by P. Skafish. Minneapolis: University of Minnesota Press.

Zerner, C. 2003. Sounding the Makassar Strait: the poetics and politics of an Indonesian marine environment. In Culture and the question of rights: forests, coasts, and seas in Southeast Asia, ed. C. Zerner, 56108. Durham: Duke University Press.

Publisher's note Springer Nature remains neutral with regard to jurisdictional claims in published maps and institutional affiliations. 